\title{
Diplomacia e multilingüismo no Direito Internacional
} Diplomacy and multilinguism in International Law

EVANDRO MENEZES DE CARVALHO*

Rev. Bras. Polít. Int. 49 (2): 178-195 [2006]

\section{Introdução}

As pesquisas no âmbito do Direito Internacional costumam dar pouca atenção a dois aspectos inter-relacionados que participam de modo decisivo na criação deste ramo do direito. São eles: as negociações diplomáticas destinadas à elaboração dos compromissos jurídicos, e o papel das línguas na elaboração e na evolução do próprio Direito Internacional. Presentes no processo de negociação para a elaboração de normas jurídicas, a diplomacia e as línguas estão a serviço das estratégias de composição e de diferença de posições desejadas pelos atores da cena internacional.

Eis por que uma eventual ambigüidade do discurso diplomático, antes de ser um vício que se deve evitar a qualquer custo, pode se apresentar como um tipo de virtude, uma competência lingüística na qual se espera serem versados os diplomatas. Ambigüidade da palavra que permite ao seu emissor situar-se estrategicamente entre o consenso e o dissenso, entre o "não" e o "sim", de maneira a conceder-lhe uma margem de ação política sem pô-lo em contradição com seus termos, preservando a sua credibilidade de negociador.

É certo que não se exclui a possibilidade de encontrarmos discursos diplomáticos marcados por tomadas de posição que se pretende explícitas e redigidos com o intuito deliberado de afastar quaisquer dúvidas quanto ao sentido das palavras por eles veiculadas. Mas, de todo modo, quando se trata de uma relação de contraposição, onde ambas as partes defendem suas posições e seus interesses, as alternativas incompatíveis (mas não contraditórias, pois neste caso seriam mutuamente excludentes) tendem a ser objeto de um penoso e meticuloso trabalho de aproximação dos sentidos das propostas textuais apresentadas a fim de se chegar a um consenso possível.

* Doutor em Direito Internacional pela Faculdade de Direito da Universidade de São Paulo - USP, mestre em Integração Latino-americana pela Universidade Federal de Santa Maria - UFSM (evandro.carvalho@gmail.com). 
O que se negocia são as expressões e seus valores semânticos correspondentes. É na negociação, segundo observa Philip Allott, que "o mundo apaixonado e desprovido de formas da política renasce como um mundo de palavras. Questóes de grande conseqüência prática, talvez envolvendo vida e morte em grande escala, são concentradas na pequenina massa de umas poucas palavras, em uma espécie de guerra de trincheiras ritualizada, em que grandes vitórias são medidas em pequenos ganhos de território verbal" (grifo nosso). ${ }^{1} \mathrm{O}$ domínio do discurso da diplomacia torna-se um requisito importante para o êxito da negociação. Permite que as partes interessadas possam se entender e ter o poder de se fazerem compreender de modo cada vez mais claro, se assim desejarem.

A linguagem diplomática, com todas as suas peculiaridades, constitui um importante instrumento utilizado pelos sujeitos de Direito Internacional em suas atividades de negociação e, sendo assim, antecede e determina a conformação do próprio Direito Internacional. Este, uma vez instituído, e na medida em que constitui a ordem jurídica internacional, servirá de quadro de referência para novas práticas discursivas diplomáticas. Percebe-se, assim, que o discurso diplomático tem uma relação estreita com o Direito Internacional. A realização deste último está condicionada pela existência do primeiro, que, por sua vez, muito se baseia nas normas jurídicas anteriormente fixadas pelo mesmo processo de criação.

Cumpre destacar aqui o problema da escolha de uma língua comum para se negociar e veicular o texto jurídico resultante das negociações internacionais. Este tema revela uma série de questóes que os teóricos do Direito Internacional pouco tem se debruçado. A principal delas diz respeito à dificuldade de se neutralizar as diferenças semânticas entre os discursos dos negociadores e entre as distintas versões lingüísticas dos acordos internacionais por eles firmados. Esta neutralidade estaria refletida na tentativa dos redatores de evitar o emprego de termos demasiadamente associados a uma determinada cultura jurídica. O inglês jurídico, por exemplo, como diz Stéphane Chatillon, "veicula os conceitos da common law e seu emprego nas relaçôes entre parceiros que não pertencem a esta cultura jurídica pode conduzir a erros ou a inépcias" (grifo no original). ${ }^{2}$

Eis por que um estudo que enfoque os discursos do Direito Internacional não deve se eximir de enfrentar o problema da diversidade lingüística e cultural presente na sociedade internacional. Afinal, o paralelismo das versões lingüísticas de um tratado não garante a identidade entre elas. Como observa Daniel Jutras, "não há a certeza de que as versões, após passarem inevitavelmente pelo filtro cultural de línguas e de tradiçôes jurídicas diferentes, produzam o mesmo

\footnotetext{
${ }^{1}$ ALLOTT, Philip. The concept of international law. European Journal of International Law (EJIL), v. 10, $\mathrm{N}^{\circ} 1,1999$, p. 46

2 CHATILlON, Stéphane. Droit et langue. Revue International de Droit Comparé, No 3, juil.-sept. 2002, p. 715.
} 
efeito e evoluam da mesma maneira para ambas." ${ }^{3}$ Denys Simon já advertia da possibilidade de os Estados, mesmo agindo de boá-fé, associarem um sentido diferente aos mesmos termos de um tratado, "considerando as diversidades lingüísticas ou jurídicas nacionais." ${ }^{4}$ Estes problemas de equivalência na interpretação de expressões são inerentes ao plurilingüismo e ao multiculturalismo jurídico do sistema internacional. Estudá-los pode nos ajudar a compreender o papel ativo da língua na construção de uma cultura jurídica global e aquilatar a importância de se explorar as possibilidades de sentido das palavras que são negociadas em uma negociação internacional.

Neste artigo se visa chamar a atenção para a importância do discurso diplomático na evolução do Direito Internacional. Enfocaremos o problema da escolha de uma língua comum e o desafio de se redigir e interpretar versões lingüísticas de textos jurídicos de acordo com a vontade das partes envolvidas na negociação. A tradução ocupa aqui um papel central. Ela nos ajuda a compreender o papel ativo das línguas na elaboração destes documentos jurídicos. Para o desenvolvimento deste tema, tomaremos como referência o debate em torno do processo global de "americanização do direito".

A diversidade lingüística e cultural do sistema internacional traz sempre novos desafios para o estudo do processo de negociação e de interpretação do Direito Internacional.

\section{O discurso diplomático e o problema da escolha de uma língua comum}

Uma questão central para as negociações internacionais diz respeito à escolha de uma língua comum de referência. $\mathrm{Na}$ história da diplomacia, a interdependência entre língua e nacionalidade associada a pontos de vistas nacionalistas foi um dos obstáculos para a solução deste problema. A língua nacional resistia às influências das línguas estrangeiras capazes de enfraquecer o seu poder na formação da consciência nacional. A ameaça do idioma estrangeiro residia na pressuposição de que o seu conhecimento atrairia, como consequiência, todo um conjunto de informações culturais relacionadas ao país do idioma em questão.

Para Benedict Anderson, a língua nacional teria sido criação de uma elite administrativa ou culta, transformada em uma espécie de modelo para a comunidade maior da "nação". Estas línguas recebiam o status de "línguasdo-poder". 5 A língua dos Estados modernos seria, assim, a língua oficial da

\footnotetext{
3 JUTRAS, Daniel. Énoncer l'indicible: le droit entre langues et traditions. Revue Internationale de Droit Comparé, No 4, oct.-déc. 2000, p. 786.

${ }^{4}$ SIMON, Denys. L'interprétation judiciaire des traités d'organisations internationales: morphologie des conventions et fonction juridictionnelle. Paris: Pedone, 1981, p. 130-131.

5 ANDERSON, Benedict. Nação e consciência nacional, São Paulo: Ática, 1989, p. 46 a 55.
} 
elite dominante, construída e imposta por meio da educação pública, dos mecanismos administrativos e com o apoio da atividade editorial, notadamente da imprensa, que teria contribuído para conferir uma fixidez à língua, fazendoa parecer "eterna". Por se instituírem com base em uma elite que controlava o poder estatal, as línguas seriam mais propriamente "de Estado" do que "nacionais".

O princípio da soberania associado ao da igualdade jurídica entre os Estados serviu não só para justificar medidas de políticas lingüísticas internas, mas também para apoiar as iniciativas de proteção e promoção da língua nacional nos foros internacionais. Com base nestes princípios, os Estados viamse autorizados a fazer uso de seu idioma oficial ao se comunicarem com outros países. A igualdade entre os entes soberanos incluiria a prerrogativa da igualdade lingüística. Para Alexander Ostrower, esta atitude teria caracterizado a teoria e a prática da diplomacia em todos os períodos da história. ${ }^{6}$ Mas a condução das relaçōes internacionais por intermédio das línguas oficiais dos Estados, apesar de satisfazer as aspirações e o orgulho dos governantes, gerou obstáculos que de outra forma não existiriam, caso se optasse pelo uso de um idioma comum.

A utilização de uma mesma língua permitiria criar um padrão mínimo de comunicação - com a ressalva de que ela, como bem observou Pierre Bourdieu, constitui não só a condição da produção econômica, mas também da dominação simbólica. ${ }^{7}$ Assim, a conveniência e a necessidade de adotar-se uma forma lingüística comum para a comunicação interestatal decorre das vantagens de ordem prática e das relaçôes de poder.

\section{A guerra das línguas na diplomacia}

Louis-Jean Calvet sustenta a idéia de que a história das línguas, sendo um capítulo da história das sociedades, é marcada por uma relação de violência umas contra as outras - "porque, se há guerra de línguas, é porque há plurilingüismo" (grifo no original). ${ }^{8}$ Esta visão hobbesiana das inter-relações lingüísticas não ignora as iniciativas de gestão deste plurilingüismo. O mercado é o exemplo maior. Afinal, "pelo número de línguas que ele põe, em certos casos, face a face, e pela necessária comunicação que ele implica (valorizar sua mercadoria, chamar o cliente, perguntar os preços, discuti-los...), é efetivamente um bom revelador da gestão do plurilingüismo que pode constituir a prática social (grifo no original)." ${ }^{\prime 9}$ Mas esta afirmação não afasta o autor de sua idéia central.

\footnotetext{
${ }^{6}$ OSTROWER, Alexander. Language, law and diplomacy: a study of linguistic diversity in official international relations and international law. Philadelphia: University of Pennsylvania, 1965. v. 1, p. 732.

7 BOURDIEU, Pierre. ¿Qué significa hablar? Economía de los intercambios lingüisticos. 2. ed. Madrid: Akal, 1999, p. 19.

${ }^{8}$ CALVET, Louis-Jean. La guerre des langues et les politiques linguistiques. Paris: Hachette, 1999, p. 10.

${ }^{9}$ Ibid., p. 108.
} 
A conseqüência lógica de uma guerra das línguas seria a supremacia de uma sobre as outras, de modo a consagrar, no limite, a existência de uma única língua universal. $\mathrm{O}$ caráter de universalidade de tal língua seria alcançado após uma longa batalha terminológica travada com outros idiomas que seriam eliminados do mapa. Este ideal da universalidade lingüística é aqui concebido por meio de um processo de disputa, diferenciando-se de outras perspectivas mais pacifistas onde a universalidade não implicaria o aniquilamento de outros sistemas lingüísticos.

De todo modo, a uniformidade lingüística seria atinente aos significantes ${ }^{10}$ de uma língua adotada em escala mundial. Isto não erradicaria totalmente os 'ruídos' nos processos comunicativos internacionais pois não eliminaria os problemas que surgem na determinação do sentido da mensagem comunicada. Afinal, os interlocutores podem não compartilhar da mesma visão de mundo. A despeito de utilizarem as mesmas expressōes, os conteúdos a elas vinculados podem ser diferentes porque distintas são as culturas dos interlocutores.

Para James Boyd White, insistir na adequação da língua universal é um tipo de tirania. Segundo ele, deve-se reconhecer que os inúmeros idiomas presentes no planeta não podem ser adequadamente traduzidos em uma "superlíngua", e é neste plurilingüismo onde residiria, paradoxalmente, a radical igualdade entre os indivíduos.

Pois se todos nós falamos diferentemente, e não existe nenhuma superlíngua em que essas diferenças possam ser definidas e julgadas, o que é necessariamente exigido é uma espécie de negociação entre nós, eu da minha posição - imbuído da minha língua e cultura - e você das suas. Nós podemos e fazemos julgamentos, mas precisamos aprender que eles são limitados e incertos; eles podem representar o que pensamos, e nesse sentido, podem ser bem firmes, porém eles também devem refletir o reconhecimento de que tudo isso poderia parecer diferente desde outros pontos de vista. ${ }^{11}$

A defesa do plurilingüismo recebe importante apoio de Claude Hagège em seu trabalho intitulado La souffle de la langue. Sua proposta, referente à realidade lingüística européia, vai de encontro às tendências favoráveis à adoção de um idioma comum. Diz ele:

A Europa das línguas tem um destino que lhe é próprio, e não saberia se inspirar em modelos estrangeiros. Se a adoção de uma língua única aparecesse nos Estados-Unidos, para cada novo emigrante, como um carimbo de identidade, o que faz a originalidade da Europa é, ao contrário, a imensa diversidade das línguas e das culturas que elas refletem. A dominação de um idioma único, como o inglês, não responde a este destino,

\footnotetext{
10 O termo "significante" é aqui considerado como sendo a "expressão" da palavra, isto é, a face concreta (audível, visível ou tangível) da palavra que o sujeito detecta antes de associá-la a um conteúdo.

11 WHITE, James Boyd. Justice as translation: an essay in cultural and legal criticism. Chicago, London: The University of Chicago Press, 1994, p. 264.
} 
mas sim a abertura permanente à multiplicidade. $\mathrm{O}$ europeu vive em plurilingüismo. Ele deverá educar seus filhos e suas filhas na variedade das línguas, e não na unidade. Tal é, ao mesmo tempo, para a Europa, o apelo do passado e do futuro. ${ }^{12}$

Vale destacar, contudo, que o próprio Claude Hagège não ignora a função do inglês como língua comum na Europa. ${ }^{13}$ Mas esta concessão do autor não é feita sem algumas considerações. Ressalta ele que "o poder do inglês" é de alguma forma promovido pelos países que falam este idioma. Neste sentido, "as vias da hegemonia são ainda hoje aquelas que existiram no Império romano. Uma potência econômica mundial determina-se tanto a servir sua língua como a conquistar mercados para seus produtos. As duas empresas são, de resto, solidárias, porque a exportação da língua, de maneira natural, abre o caminho para aquela das mercadorias". ${ }^{14}$ A promoção de uma língua comum tem um propósito político e econômico evidente, e seu domínio tem uma importância considerável no aumento da competitividade de um país em suas relações internacionais.

A predominância do inglês é discutida por Robert Phillipson em seu livro intitulado Linguistic imperialism. Nesta obra, a partir do viés lingüístico, o autor ocupa-se das relações estruturais entre países ricos e pobres e os mecanismos pelos quais a desigualdade entre eles é mantida. Uma reflexão é particularmente interessante:

Para nossos propósitos, é necessário estabelecer o imperialismo lingüistico como um tipo distinto de imperialismo para sermos capazes de avaliar o seu papel dentro de uma estrutura imperialista como um todo. O imperialismo lingüistico permeia todos os tipos de imperialismo por duas razôes: a primeira diz respeito à forma (a língua como um meio de transmissão de idéias), a segunda, ao conteúdo (grifo nosso). ${ }^{15}$

Para o autor, o imperialismo lingüístico é um componente primário do imperialismo cultural. Por meio dele fornece-se não só um sistema de significantes a ser compartilhado, mas exportam-se conteúdos culturais para dentro de outros idiomas e, conseqüentemente, de outras culturas.

Obtém-se a supremacia de um sistema de $\operatorname{signos}^{16}$ lingüísticos tanto por meio da difusão e prevalência de seus significantes, como por meio da

\footnotetext{
12 HAGÈGE, Claude. Le souffle de la langue. Paris: Odile Jacob, 2000, p. 8-9.

${ }^{13}$ As informaçōes contidas no sítio eletrônico da União Européia corroboram a posição do autor. O inglês é a língua mais "falada" da União Européia. Dos $47 \%$ dos cidadãos que a falam, $16 \%$ a têm como sua língua materna e $31 \%$ a falam "suficientemente bem para manter uma conversa". Para mais informações consultar: http://europa.eu.int/comm/education/policies/lang/languages/lang/europeanlanguages_pt.html. ${ }^{14}$ HAGËGE, Claude. Le souffle de la sangue, Op. cit., p. 42.

15 PHILlIPSON, Robert. Linguistic imperialism. Oxford: Oxford University Press, 1993, p. 53.

$16 \mathrm{O}$ "signo" pode ser aqui entendido como sendo "tudo quanto, à base de uma convenção social previamente aceita, possa ser entendido como algo que está no lugar de outra coisa (grifo no original)." (ECO, Umberto. Tratado geral de semiótica, 3. ed. São Paulo: Perspectiva, 2000, p. 11,. Neste trabalho, o signo lingüístico pode ser compreendido como sendo o resultado da combinação entre o significante e o significado de uma palavra.
} 
disseminação e fixação de seus significados. O êxito desta empreitada favoreceria outras formas de imperialismo. Entretanto, a organização dos conteúdos veiculados por uma língua dá-se de modo diferente e mutuamente indeterminável em cada país ou cultura. Afinal, como adverte Umberto Eco, a "palavra" só mantém a sua pureza se não for difundida, do contrário, "ela se 'babeliza"' 17 . Disseminar um sistema de signos não é só compartilhar suas expressôes, mas realimentá-lo, ampliando suas possibilidades de sentido para novas e outras práticas de comunicação e difusão.

A despeito dos riscos de divergências semânticas, o uso de uma língua comum responde às necessidades de comunicação entre os povos, entre os governos, os comerciantes, etc. Uma competição lingüística não contribuiria para o encorajamento de um modus vivendi no sistema internacional. Por este motivo, a escolha de um idioma comum é sempre o primeiro passo para o diálogo diplomático.

\section{A busca da "terceira coisa" na negociação do discurso jurídico internacional}

O discurso do Direito Internacional é um tipo de discurso diplomático, resultado da atividade da diplomacia. Trata-se de um dos instrumentos privilegiados de comunicação no âmbito do sistema internacional. Poder fazer uso do mesmo significa ter a capacidade de agir juridicamente neste sistema. Tal discurso é veiculado por meio dos tratados internacionais. É considerado jurídico em virtude de seu valor normativo, e diplomático pelo fato de que seu texto decorre do exercício da diplomacia bilateral ou multilateral.

Mas o que este discurso pode ainda ter de característico? De maneira criativa e esclarecedora, Péter Kovacs explica que a legislação internacional, por originar-se de um complexo processo de negociação, tem algo em comum com o salame: "é melhor não estar presente durante sua preparação para poder apreciar o seu gosto". ${ }^{18}$ Uma declaração espirituosa que chama a atenção para a complexidade do processo de negociação do conteúdo do texto normativo convencional. Para o autor, "a negociação e principalmente a redação do texto dos tratados internacionais são portadores de compromissos políticos e de concessôes favorecendo muitas vezes a aceitabilidade, mas não a compreensão do texto elaborado." ${ }^{19}$ Como diz Gérard Cornu, "a política está na palavra”. ${ }^{20} \mathrm{O}$ tratado resultante das negociações seria uma colcha de

\footnotetext{
17 ECO, Umberto. A busca da língua perfeita na cultura européia. Bauru: EDUSC, 2001, p. 384.

18 KOVACS, Péter. Developpement et limites de la jurisprudence en droit international. In: La juridictionnalisation du droit international. Paris: Pedone, 2003, p. 269.

19 Ibid., p. 269.

${ }^{20}$ CORNU, Gérard. Linguistique juridique, 2e. éd. Paris: Montchrestien, 2000, p. 317.
} 
retalhos que se espera cobrir (atender a) todos os interesses visados pelas partes envolvidas. Estas, porém, podem possuir distintas pretensões e atribuir diferentes sentidos a respeito do que foi fixado no acordo internacional.

As negociações são levadas a efeito com base das propostas textuais de tratado preparadas com antecedência pelos Estados. O nó górdio da negociação repousa na procura por "formas de palavras" aceitáveis para todos os participantes. Afinal, conforme observa Yves Delahaye, "o negociador que penou durante semanas ou meses sobre um projeto de acordo, dá naturalmente mais importância a este do que a outro texto ou palavra que ele ouviu ou mesmo pronunciou ao longo do debate, qualquer que seja seu orgulho de autor" 21 . É neste sentido que, para Philip Allott, a negociação constitui um processo que visa a encontrar uma "terceira coisa", que nenhuma das partes quer, mas que mesmo assim pode aceitar. Este entendimento motivou o próprio autor a sugerir uma curiosa definição para "tratado": "um tratado é um desacordo reduzido a escrito." 22

A primeira conseqüência deste entendimento é que o discurso jurídico veiculado nos tratados não reflete necessariamente a vontade real de todos os Estados que o negociaram. Seja no que diz respeito ao conteúdo, seja quanto à forma, o discurso em questão, via de regra, difere daquele que cada um dos Estados, considerados isoladamente, teria desejado e apresentou na fase de negociações. Isto é particularmente comum no seio das organizações internacionais. A segunda conseqüência é que tal discurso, apesar de encerrar a fase de negociação, inicia um outro processo: o da disputa pelo significado da chamada "terceira coisa". Ou seja, a palavra que outrora permitiu o consenso entre os negociadores passa a motivar novas divergências. Presas à "forma da palavra" que foi consagrada no texto do tratado, as partes direcionam os seus olhares para o conteúdo. Trata-se de uma batalha de cunho semiótico geralmente transferida para os mecanismos de solução de controvérsias.

Os órgãos decisórios chamados para examinar a disputa sobre os conteúdos das palavras terão a incumbência e a oportunidade de eliminar as eventuais incertezas e as ambigüidades lingüísticas do discurso do Direito Internacional. Mas a análise deste discurso reveste-se de uma complexidade adicional por se operar em um sistema multilíngüe. Isto quer dizer que o seu limite é o mesmo de qualquer outra língua natural: pressupõe um princípio de traduzibilidade. Isto é, prevê que seus discursos possam ser vertidos para outras línguas, apesar de cada uma possibilitar formas diferentes de perceber, organizar e interpretar o direito.

\footnotetext{
${ }^{21}$ DELAHAYE, Yves. La frontière et le texte: pour une sémiotique des relations internationales. Paris: Payot, 1977 , p. 28.

${ }^{22}$ ALLOTT, Philip. The concept of international law, Op. cit., p. 43.
} 


\section{A tradução do Direito Internacional}

A intensificação das relações internacionais e a conseqüente multiplicidade de acordos jurídicos conferem ao fazer tradutório uma importância pouco considerada pelos juristas. A necessidade de tradução decorre diretamente da necessidade de comunicação e esta existe tanto no interior de uma mesma língua, como entre duas línguas onde a mediação do tradutor se impõe.

O termo "traduzir" é um composto prefixado que tem como fonte latina a expressão transducere, do prefixo trans- ("através") aplicado ao verbo ducere ("conduzir"). Outro paralelo pode ser feito com o verbo latino transferre, de ferre, "levar", "trazer". Ambas as expressões transmitem um sentido de "transferência", de "transporte", de "levar ou trazer por meio de", o que autoriza propor uma definição de tradução como sendo o traspassar das fronteiras de um texto por meio da condução de seus significados para o território das formas expressivas de uma outra língua. A situação-tipo em que a tradução se impõe é aquela em que há um bloqueio parcial ou total na relação comunicativa emissor'! receptor. Tal bloqueio decorre de interferências na comunicação provocadas por variações lingüísticas. É o caso, geralmente, de o receptor não ter um conhecimento satisfatório do vocabulário empregado pelo emissor. A configuração desta situação-tipo é a seguinte:

Figura 1

Emissor 1 $\rightarrow \begin{gathered}\text { Enunciado } \\ \text { na língua de } \\ \text { partida }\end{gathered} \rightarrow$ (bloqueio) Receptor 1 $\Rightarrow$ Emissor 2 $\rightarrow \begin{gathered}\text { Enunciado } \\ \text { na língua de } \\ \text { chegada }\end{gathered} \rightarrow$ Receptor 1

A superação do bloqueio na comunicação dá-se com a retomada da relação emissor-receptor por meio de um novo ato comunicativo, o ato tradutório. É por isto que devemos considerar a tradução não apenas como um mero intercâmbio de signos lingüísticos ou um simples processo de transcodificação do texto original, pois o tradutor não deve negligenciar que a tradução é destinada também a estabelecer novos processos de comunicação. $O$ tradutor é o emissor do texto a ser produzido na língua de chegada (Emissor 2 da figura 1), viabilizando a comunicação entre dois sujeitos: o Emissor 1 e o Receptor 1. Por intermédio da tradução, uma segunda relação comunicativa substitui a primeira, buscando estabelecer uma aproximação entre os conteúdos das línguas em presença. É um processo de comunicação bilíngüe que leva em conta a dimensão cultural dos falantes.

Neste sentido, pode-se admitir a possibilidade de que um texto jurídico escrito em português de Portugal, possa ensejar sua tradução para o português falado no Brasil. Tal situação ocorre porque conteúdos culturais do primeiro 
sistema de signos, no qual foi escrito o texto original, diferem daqueles encontrados na língua do texto da tradução. Traduz-se cultura e não apenas signos lingüísticos. Maher Abdel Hadi traz alguns exemplos a respeito de expressões utilizadas por países de língua francesa:

O tradutor inglês ou árabe ao traduzir um texto jurídico belga para o inglês ou o árabe ficará perplexo diante de algumas expressões como, por exemplo, o termo 'parastatal que designa na Bélgica o que está à margem do Estado enquanto que, no direito francês, é totalmente desconhecido e não aparece no Larousse. Por outro lado, a noção jurídica abrangida por este termo existe no direito francês, mas ela é envolvida por uma outra expressão. Os 'organismes parastataux' da Bélgica correspondem, na França, às 'collectivités publiques' (grifo no original). ${ }^{23}$

Vê-se que a tradução deve tomar o conteúdo como o seu objeto e, sendo assim, não se limita a comparar expressões. O conteúdo está longe de ser estático e dado objetivamente, tal como aparenta ser a face expressiva do signo lingüístico. Isto quer dizer que entre o significante e o significado do texto "original" existe uma correlação culturalmente sedimentada onde se instala o problema fundamental da tradução. É por este motivo que o francês jurídico, o belga ou o da África francófona possuem suas próprias peculiaridades de sentido. As particularidades da língua e a diversidade cultural contribuem para o surgimento de problemas práticos decorrentes da não concordância da linguagem do direito de um sistema jurídico em relação a um outro.

O esforço do tradutor consiste em localizar os significados do texto jurídico de origem e retransmiti-los em um outro sistema de signos lingüísticos. $\mathrm{O}$ ato de traduzir não seria apenas uma simples trasladação de lexemas com a conseguinte adequação de sua estrutura sintática. É insuficiente dizer que se trata de uma operação de representação de um vocábulo por um outro correspondente em uma outra língua. É, antes, um ato que envolve a compreensão e a transmissão do sentido do texto original.

A problemática da relação entre o texto original e o texto da tradução está em ver este último como sendo uma mediação do primeiro que, por sua vez, passa a ocupar o lugar da "coisa-em-si", isto é, o lugar do significado que a tradução apenas substitui. Desde esta perspectiva a tradução estaria para o "original" - lugar onde repousariam os significados que supostamente estariam a salvo da relatividade do sentido. Mas todo "original", como os signos que o constituem, é também mediação e, portanto, também provisório e secundário. É o que sublinha Rosemary Arrojo:

${ }^{23}$ HADI, Maher Abdel. Géographie politique et traduction juridique: le problème de la terminologie. Terminologie et Traduction, $\mathrm{N}^{\circ} 2 / 3,1992$, p. 49-50. 
[...] o significado não se encontra para sempre depositado no texto, à espera de que um leitor adequado o decifre de maneira correta. $\mathrm{O}$ significado de um texto somente se delineia, e se cria, a partir de um ato de interpretação, sempre provisória e temporariamente, com base na ideologia, nos padrōes estéticos, éticos e morais, nas circunstâncias históricas e na psicologia que constituem a comunidade sociocultural [...] - em que é lido. O que vemos num texto é exatamente o que nossa 'comunidade interpretativa' nos permite ler naquilo que lemos... [...] Assim, nenhuma tradução pode ser exatamente fiel ao 'original' porque o 'original' não existe como um objeto estável, guardiāo implacável das intençôes originais de seu autor (grifo nosso). ${ }^{24}$

Isto é assim porque não há no discurso original um significado que se refira a si próprio, mas sim a algo que está 'fora' dele mesmo, qual seja, a realidade culturalmente constituída. Logo, será frustrada toda tentativa de tradução que tente reproduzir a totalidade de sentido do discurso 'original', exatamente porque não há esta 'totalidade', posto que não há texto que esteja imune a diversas leituras.

Não se transporta um significado do discurso original sem correr o risco de promover alguma alteração em seu sentido. Para James Boyd White, no processo de tradução "sempre há ganho e perda, sempre há transformação; o 'significado original' do texto não pode ser nosso significado, pois ao reformulálo em nossos termos, em nosso mundo, não obstante o quão fielmente ou literalmente, nós produzimos algo novo e diferente". ${ }^{25}$ A própria atividade de tradução de discursos jurídicos não escaparia imune a estas modificaçōes na transposição de significados jurídicos, exigindo do tradutor uma contínua reflexão sobre o discurso a ser traduzido e sobre o contexto legal no qual o mesmo se insere.

Isto não implica que o discurso jurídico possa ser recriado livremente em outro idioma, mas, sim, que é improvável uma tradução capaz de exprimir com exatidão todos os significados por ele veiculados, ou que reproduza 'fielmente' a intenção do autor. Isto porque na passagem de uma língua para outra tende-se a mudar de um universo referencial para outro, podendo envolver realidades distintas, de cultura a cultura. A apreensão do texto original deve ser efetuada tendo por pano de fundo o quadro referencial da língua/cultura de chegada, fazendo com que o produto final - o texto da tradução - possa conter expressōes cujos sentidos não coincidem exatamente com o discurso de origem. Aquilo que parece culturalmente bem definido em uma língua pode apresentar-se obscuro ou ambíguo em uma outra. Por estes motivos é que a tradução jurídica, mesmo vinculada (em maior ou menor grau) ao texto original, recria um novo texto em uma outra língua. O êxito do ato de tradução depende

${ }^{24}$ ARROJO, Rosemary. Tradução, desconstrução e psicanálise. Rio de Janeiro: Imago, 1993, p. 19.

25 WHITE, James Boyd. Justice as translation, Op. cit., p. 241. 
da competência referencial e lingüística do tradutor que deve estar consciente dos riscos deste ato sobre vida dos destinatários do direito traduzido.

\section{O papel ativo da língua estrangeira}

O tema da tradução do direito ajuda-nos a revelar o poder da língua estrangeira na construção e na disseminação de uma cultura jurídica sobre outra no âmbito do sistema internacional. A noção de poder é aqui associada à força social do discurso veiculado no texto jurídico convencional. Desde esta perspectiva, tal poder é diretamente proporcional ao seu efeito na consolidação de uma realidade juridica compartilhada pela sociedade internacional, aumentando as possibilidades de eficácia do Direito Internacional e investindo o seu conteúdo de legitimidade.

O ponto de partida para o desenvolvimento deste raciocínio é a obra de Stéphane Beaulac intitulada The power of language in the making of international law. $\mathrm{O}$ autor desenvolve seu estudo a partir da noção de que a linguagem, por meio do processo cognitivo da mente humana, pode não só representar a realidade, mas também ter um papel importante na sua criação e na sua transformação, incluindo a atividade de modelagem da "consciência compartilhada da sociedade". ${ }^{26}$ Cada palavra seria, assim, uma "forma de poder social", um instrumento que poderia ser utilizado de modo a (re)constituir uma visão de mundo a incidir sobre o próprio mundo. Expressões como "Estado", "soberania", "livre comércio", "globalização", "direito", dentre outras, moldurariam a nossa percepção sobre a realidade internacional, isto é, exerceriam um papel ativo sobre a nossa compreensão do sistema internacional como ele foi, é e como ele pode ser.

A linguagem é vista como um instrumento que modela a realidade e, como as palavras mudam, a realidade ajustar-se-ia de maneira apropriada para as circunstâncias em particular. A alteração da língua, concernente à introdução de um novo significado por intermédio de um novo significante, reclamaria um ajuste da realidade. Mas não exclui a via inversa. Um dado novo da realidade poderia requerer daquela mesma língua uma modificação no seu plano do conteúdo. No primeiro caso a linguagem assume uma função ativa; e, no segundo, passiva. Assim, se as transformações na realidade ocasionam alteraçóes em nosso conhecimento sobre o mundo, as palavras poderiam, por sua vez, constituírem-se em instrumentos de produção de novos conteúdos sobre a realidade e, por conseguinte, construírem novas e outras realidades.

A dinâmica do processo cognitivo é que está na base das alterações sobre as duas dimensões em questão: a da realidade extralingüística e a da palavra

${ }^{26}$ BEAULAC, Stéphane. The power of language in the making of international law: the word sovereignty in Bodin and Vattel and the myth of Westphalia. Leiden; Boston: Martinus Nijhoff Publishers, 2004, p. 1. 
"concretamente" considerada. As mudanças em nossa percepção efetuadas pela primeira conduzem-nos a retê-las no intelecto e nomeá-las para propósitos de significação e comunicação. Por outro lado, as mudanças da nossa percepção sobre aquela 'realidade' conduzem-nos a renomeá-la tendo em conta os conteúdos de consciência construídos mentalmente.

$\mathrm{O}$ que queremos destacar no momento, quanto a este ajuste da percepção da realidade pelo fato da linguagem, é a palavra considerada dinamicamente como elemento que contribui para a criação de novas visões de mundo. Assim é que, para Philip Allott,

Nossas palavras criam nossos mundos. Escolher nossas palavras é escolher uma forma de vida. Escolher nossas palavras é escolher um mundo. Confrontar palavras é confrontar uma forma de vida e um mundo. Modificar palavras é modificar uma forma de vida e um mundo. Podemos criar novas formas de vida social, novos mundos sociais ao escolher novas palavras coletivamente, incluindo as novas palavras constantemente criadas através da redefinição de palavras antigas. Criar uma nova palavra ou alterar o significado de uma velha palavra é tornar possível novas realidades. ${ }^{27}$

É particularmente em relação a este papel ativo da linguagem que se vislumbra a possibilidade dos signos lingüísticos exercerem um poder na construção social da realidade. Esta força social da língua participa do processo de formação de uma cultura jurídica global fortemente influenciada pelas culturas jurídicas dos países de língua inglesa, notadamente dos Estados Unidos.

\section{O poder da língua inglesa na americanização do direito}

Para desenvolver este tópico exploraremos melhor a função ativa da língua retomando, brevemente, o tema da tradução. Esta é vista por Reib e Vermeer como "um tipo especial de transferência de valores culturais" (grifo nosso). ${ }^{28}$ Newmark, por sua vez, entende que a tradução é usada "tanto para transmitir conhecimento e propiciar a compreensão entre grupos e nações, como também para transmitir cultura" (grifo nosso). ${ }^{29} \mathrm{Na}$ medida em que importa o conteúdo do texto original para uma outra língua, a tradução constrói uma ponte entre duas culturas que, a partir de então, estabelecem contatos entre si. Transportase, pois, um conteúdo cultural, uma visão de mundo que pode ou não se chocar, adequar-se, identificar-se ou influenciar a outra língua/cultura de chegada.

Estas considerações são relevantes quando encontramo-nos na esfera do Direito Internacional. A operação intelectual própria da tradução é, ainda que

27 ALLOTT, Philip. Eunomia: new order for a new world. New York: Oxford University Press, 1990, p. 6. 28 Apud AZENHA JUNIOR, João. Tradução técnica e condicionantes culturais: primeiros passos para um estudo integrado. São Paulo: Humanitas/FFLCH/USP, 1999, p. 31.

29 NEWMARK, P. Apud. Ibid., p. 31. 
inconscientemente, freqüente no processo de negociação de um acordo internacional. Trata-se de um procedimento mental de que lançam mão os negociadores para se comunicarem em um sistema marcado pelo plurilingüismo e pelo multiculturalismo jurídico. Mesmo o uso de uma única língua de trabalho (por exemplo, o inglês), não eliminaria o papel ativo da linguagem. Isto é válido não só para os falantes de outros idiomas, mas também para os próprios negociadores que encontram no inglês sua língua de domínio mais ativo. Em qualquer caso, a tradução para a língua de trabalho dos conteúdos jurídicos negociados é um método que permite saber o que se está negociando. Afinal, o que é trazido à mesa de negociação, via idioma de expressão comum, é o conteúdo cultural - ou, na expressão de Pierre Bourdieu, o capital cultural que é o capital jurídico. ${ }^{30}$ Este, por si só, bastante para garantir posiçôes de poder.

A função ativa da linguagem nas relações internacionais está associada ao "papel histórico" - ou "ativo", como utilizamos - da palavra estrangeira no processo de formação de todas as civilizações. Para Mikhail Bakhtin,

A palavra estrangeira foi, efetivamente, o veículo da civilização, da cultura, da religião, da organização política. [...] Esse grandioso papel organizador da palavra estrangeira - palavra que transporta consigo forças e estruturas estrangeiras e que algumas vezes é encontrada por um jovem povo conquistador no território invadido de uma cultura antiga e poderosa (cultura que, então, escraviza, por assim dizer, do seu túmulo, a consciência ideológica do povo invasor) - fez com que, na consciência histórica dos povos, a palavra estrangeira se fundisse com a idéia de poder, de força, de santidade, de verdade, e obrigou a reflexão lingüística a voltar-se de maneira privilegiada para seu estudo (grifo no original). ${ }^{31}$

Poder-se-ia conjecturar, na linha de um Louis-Jean Calvet, que o referido papel organizador da palavra estrangeira inscreve-se em meio à guerra das línguas. Mas, uma vez que esta palavra "transporta consigo forças e estruturas estrangeiras", poderíamos postular que a guerra das línguas seria apenas o epifenômeno de uma disputa mais profunda, de ordem cultural mais ampla e que, em nosso caso, abrange a dimensão jurídica. Esta hipótese parece encontrar guarida quando defrontamo-nos com o debate atual a respeito da "americanização do direito". No centro desta discussão está a indagação sobre o peso e o grau de influência da cultura jurídica estadunidense sobre os diversos direitos e práticas jurídicas de outros países. Não é outra a preocupação expressada por Antoine Garapon e Ioannis Papadopoulos: "todos os juristas (à exceção, claro, dos lawyers americanos que impuseram em quase todo lugar sua maneira de trabalhar, nivelando por sua oferta a demanda de direito) têm o sentimento de

\footnotetext{
30 BOURDIEU, Pierre. O poder simbólico. 5. ed. Rio de Janeiro: Bertrand Brasil, 2002, p. 242.

${ }^{31}$ BAKHTIN, Mikhail. Marxismo e filosofia da linguagem: problemas fundamentais do método sociológico na ciência da linguagem. 10. ed. São Paulo: Hucitec; Annablume, 2002, p. 101.
} 
viver uma certa aculturação jurídica generalizada por conta da competição entre os sistemas jurídicos." 32

A resposta de E. Allan Farnsworth para explicar a "evidente influência americana” não passa à margem do que estamos tratando neste trabalho. Deixa explícita a importância de se ter em conta, nesta discussão, as relaçôes entre direito e língua. Diz ele: "Evidentemente, como outros países vinculados à common law, os Americanos têm a vantagem de falar inglês. É difícil se lançar nos negócios internacionais sem uma certa familiaridade com a língua inglesa. Logo, ter o inglês como língua materna é um grande trunfo." 33 A influência do direito estadunidense também não é negada por Mathias Reimann. Mas ele a vê desde outro ângulo, o da cultura jurídica em seu sentido mais amplo, e não somente restrito ao direito positivo. Aquela é associada à prática jurídica, que sofre um processo de transformação como resultado da globalização do mercado de serviços jurídicos, "sob dominação americana". ${ }^{34} \mathrm{E}$ acrescenta:

Esta evolução tem também uma ligação estreita com a supremacia do inglês (americano) como linguagem jurídica internacional. Os negócios jurídicos internacionais na Europa, e aliás hoje em dia quase no mundo inteiro, empregam palavras inglesas, bases de dados americanas e mesmo freqüentemente abordagens americanas em matéria de negociação, de redação de contrato e de solução de conflitos. ${ }^{35}$

A língua apresenta-se, mais uma vez, como um fator importante para a configuração deste cenário de prestígio de um direito sobre outros. É o que sublinha também Horatia Muir Watt:

Naturalmente, é difícil conceber o prestígio jurídico independentemente daqueles outros fenômenos culturais, tais como a língua ou o modelo econômico. A atração exercida atualmente pelo direito americano sobre outros sistemas do globo se acompanha de uma ampla difusão da língua inglesa e é dificilmente dissociável da prosperidade econômica cujo direito em questão é o vetor. ${ }^{36}$

Associar o aspecto econômico ao par direito-língua traz novos elementos ao estudo do poder da língua inglesa na formação do discurso jurídico internacional que servem de contrapeso a uma abordagem marcadamente idealista que o

32 GARAPON, Antoine; PAPADOPOULOS, Ioannis. Juger en Amérique et en France: culture juridique française et common law. Paris: Odile Jacob, 2003, p. 13-14.

33 FARNSWORTH, E. Allan. L'américanisation du droit: mythes ou réalités. Archives de Philosophie du Droit, Paris: Dalloz, t. 45, 2001, p. 24.

34 REIMANN, Mathias. Droit positif et culture juridique: l'américanisation du droit européen par reception. Archives de Philosophie du Droit, Paris: Dalloz, t. 45, 2001, op. cit., p. 72.

35 Idem, loc. cit.

36 WATT, Horatia Muir. Propos liminaires sur le prestige du modèle américain. Archives de Philosophie du Droit, Paris: Dalloz, t. 45, 2001, p. 32. 
viés unicamente lingüístico poderia supor. $O$ discurso jurídico em questão não estaria dissociado da produção das condiçôes de existência material dos seus emissores e receptores. Ele exprime, no plano do Direito Internacional, as relações de força (das forças produtivas) presentes na esfera econômica no âmbito do sistema internacional. De todo modo, a língua tem um papel destacado. A exportação da língua abre caminho não só para as mercadorias, como sustenta Claude Hagège ${ }^{37}$, mas também para os conteúdos jurídicos.

\section{Conclusão}

A transposição lingüística de formulações jurídicas e de sentidos jurídicos oriundos de um meio plurilíngue e multicultural é sempre um desafio para os profissionais que trabalham com o Direito Internacional. Isto é particularmente evidente quando se está diante de versões oficiais de tratados internacionais. A igualdade de valor das múltiplas versões do acordo é, na prática, deplorada quando o texto inicialmente redigido em um dos idiomas oficiais é, em seguida, traduzido para uma outra língua também oficial. É neste sentido a advertência de Gérard Cornu:

\footnotetext{
Não é menos verdade que, quando um direito nascido em uma língua é transposto para uma outra, a igualdade de principio das duas versões não impedirá jamais que, com relação à afinidade natural que reina entre um direito e sua língua de nascimento, o sucesso da transposição seja uma conquista de alta luta, fruto do labor e da pena, o que, em realidade - a diferença é sociológica - não assegurará necessariamente uma igual recepção e uma mesma clareza à versão inevitavelmente marcada de um certo artificialismo. $^{38}$
}

Só discordaríamos destas palavras se admitíssemos a hipótese das línguas em questão terem uma mesma referência cultural e o processo intelectual dos povos envolvidos fosse idêntico, o que é difícil de se constatar e de se registrar. À parte esta ressalva, a elaboração de um tratado internacional em um determinado idioma e sua correspondente tradução para as demais línguas oficiais da organização internacional levanta questões a respeito da uniformidade de sentido dos textos em causa. A tradução ocupa, portanto, um lugar importante na abordagem do discurso diplomático e no estudo da hermenêutica do Direito Internacional.

A proximidade entre tradução e interpretação resta também evidenciada. Ela decorre do fato de que ambas são composiçóes de um texto particular como resposta a um outro texto. Tanto na tradução como na interpretação há

37 HAGÈGE, Claude. Le souffle de la langue, Op. cit., p. 42.

38 CORNU, Gérard. Linguistique juridique, Op. cit., p. 12. 
a produção de um segundo texto com referência a um outro. Isto é particularmente importante no Direito Internacional quando um acordo resultante de uma negociação internacional, e escrito inicialmente em um idioma, é traduzido para um outro idioma oficial e interpretado à luz das duas versões lingüísticas. Ressalta James Boyd White que "o efeito de tal medida não é conferir, por decreto, a ambas versões o mesmo significado, pois isto é impossível; o efeito é de simplesmente adiar o problema de diferença de idioma e torná-lo objeto de negociação em uma data posterior, quando ambos os lados propuserem construções diferentes do tratado, cada um confiando em sua própria versão." ${ }^{39}$ As diferenças de significados entre as versões do tratado seriam resolvidas ulteriormente por meio dos mecanismos institucionalizados de solução de controvérsias.

Neste sentido, pode-se afirmar que os textos das versões oficiais do tratado constituir-se-iam, de algum modo, em discursos jurídico-diplomáticos distintos tanto na forma quanto no conteúdo. Quer-se dizer que, muito embora sejam autênticos e façam igualmente fé, os discursos não são idênticos. Mas apesar de não haver identidade entre as versões, não se pode dizer que se trata de discursos totalmente incompatíveis. Como observa Francis Henrik Aubert, a relação entre original e tradução difere da relação entre dois discursos completamente díspares, uma vez que a primeira relação dá-se por meio de uma equivalência de mensagens. Mas acrescenta: "Não se trata, nem seria o caso, de uma mesma mensagem: são duas as mensagens, como são duas as 'roupagens' lingüísticas, mas visando fins comunicativos similares, que se aproximam o suficiente (sem se confundirem) para que uma seja percebida como sendo a tradução - a equivalência - da outra." (grifo no original). ${ }^{40}$

O efeito prático desta asserção seria a erosão da idéia de que a pluralidade dos suportes textuais não afetaria em nada a unidade do conteúdo do texto normativo. Há um enfraquecimento do argumento que sustenta que as versões traduzidas de tratados não operam modificações (perdas e/ou ganhos), mesmo que muito particulares, se comparadas ao discurso jurídico da versão original. Ademais, desmistifica-se o jogo ideológico que atribui apenas ao autor do "original" o poder de determinar os significados. Este poder de significar não seria unicamente do autor, mas também do tradutor - mesmo o mais 'fiel' deles - cuja intervenção não é desinteressada em relação ao original.

O discurso do Direito Internacional é construído por meio de um longo processo de negociação dos seus conteúdos, onde culturas jurídicas distintas procuram dialogar e aproximar o seu entendimento sobre o direito à luz dos objetivos que a sociedade internacional almeja. $\mathrm{O}$ desafio posto para aqueles

\footnotetext{
39 WHITE, James Boyd. Justice as translation, Op. cit., p. 245.

40 AUBERT, Francis Henrik. As (in)fidelidades da tradução: servidōes e autonomia do tradutor. 2. ed. Campinas: Editora da UNICAMP, 1994, p. 32.
} 
que trabalham com o Direito Internacional é o de compreender o sistema jurídico desde outras possibilidades de sentido, desde outras realidades culturais. Se, de um lado, isto exige do jurista, do internacionalista, do diplomata etc., competências e habilidades muito amplas e complexas, de outro, convida-nos a construir um mundo mais aberto à experiência da alteridade, oferecendo ao Direito Internacional a oportunidade de ser a expressão legítima da vontade dos povos.

Recebido em 25 de setembro de 2006 Aprovado em 5 de novembro de 2006

\section{Resumo}

No presente artigo se discute o papel do discurso diplomático e das línguas na negociação e na interpretação do Direito Internacional. A tradução ocupa um lugar central. Discutese o poder da língua estrangeira na construção deste direito e a complexidade do ato interpretativo de tratados autenticados em mais de um idioma.

\section{Abstract}

This paper discusses the roles of the diplomatic discourse and the language in the negotiation and interpretation of international law. We argue that language translation is central to the problem. We examine the power of a foreign language in the construction of international law and the complexity involved while interpreting treaties that have been validated in more than one language.

Palavras-chave: Direito Internacional, discurso diplomático, língua, interpretação, tradução. Key words: International Law, diplomatic discourse, language, interpretation, translation. 